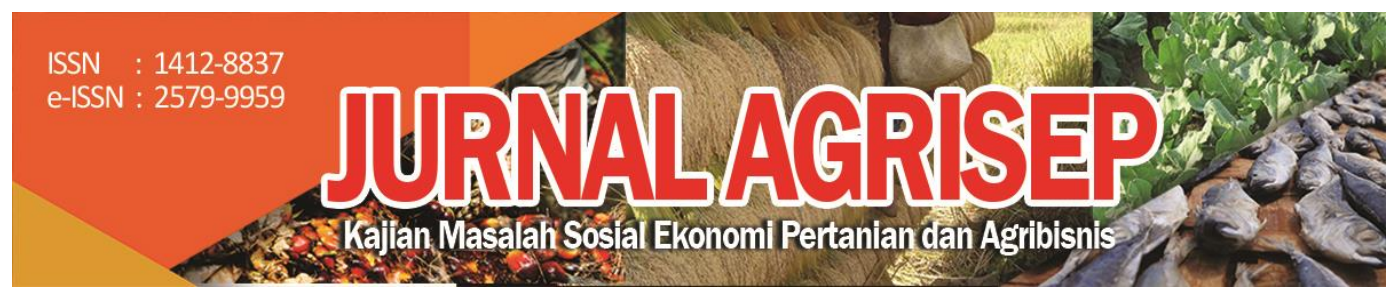

DOI: $10.31186 /$ jagrisep.20.1.55-68

\title{
KEPUASAN ANGGOTA TERHADAP PERAN KELOMPOK DALAM PELAKSANAAN PROGRAM PEMANFAATAN PEKARANGAN DI KAWASAN PERKOTAAN (STUDI KASUS DI KELOMPOK WANITA TANI KENTAGOR MANDIRI KOTA BOGOR)
}

\section{Member Satisfaction to the Role of the Group in Implementation of Yard Utilization Program in Urban Areas (Case Study in Kentagor Mandiri Women Farmers Group Bogor City)}

 \\ 1) Balai Pengkajian Teknologi Pertanian (BPTP) Bengkulu \\ 2) Departemen Agribisnis Fakultas Ekonomi Manajemen IPB University \\ Email: bundaqonita2012@gmail.com
}

\begin{abstract}
The Sustainable Home Food Area (KRPL) is the yard utilization programs that empowers community in the form of groups, one of which is Woman Farmers Group (KWT). The sustainability of program implementation is dependent on the active participation of members which influenced by satisfaction with the role of the group. This study aims to analyze the levels and attributes that determine member satisfaction to the role of the group in implementation the KRPL program. The research was conducted at KWT Kentagor Mandiri Kencana Village, Tanah Sereal District, Bogor City in December 2019-June 2020. Sample amount of 34 people were determined by census method. The data used are primary and secondary data. Primary data comes from interviews with KWT members while secondary data is obtained from literature studies and documents of related agencies. The level of member satisfaction with the group's role in implementing the yard utilization program was analyzed using the Customer Satisfaction Index (CSI) approach, while the determining factors were determined using a quadrant analysis on the Importance Performance Analysis (IPA).The results show that the members are satisfied with the performance of the group's role in implementation the KRPL program as indicated by the CSI index value of 0.80 . There are five attributes that determine members' satisfaction with the role of the group in implementation the KRPL program, namely planning learning needs, arranging group task division,
\end{abstract}


planning collaborative activities, planning the types of foodstuffs to be cultivated and facilitating the availability of seeds.

Keywords: members, women farmer group, satisfaction, yard, role

\begin{abstract}
ABSTRAK
Program Kawasan Rumah Pangan Lestari (KRPL) merupakan program pemanfaatan pekarangan yang memberdayakan masyarakat dalam bentuk kelompok,salah satunya Kelompok Wanita Tani (KWT). Keberlanjutan pelaksanaan program sangat tergantung pada partisipasi aktif anggota yang dipengarui oleh kepuasan terhadap peran kelompok. Penelitian bertujuan untuk menganalisis tingkat dan atribut penentu kepuasan anggota terhadap peran kelompok dalam pelaksanaan program KRPL. Penelitian dilaksanakan di KWT Kentagor Mandiri Kelurahan Kencana Kecamatan Tanah Sereal Kota Bogor pada bulan Desember 2019Juni 2020. Sampel berjumlah 34 orang yang ditentukan dengan menggunakan metode sensus. Data yang digunakan berupa data primer dan sekunder. Data primer merupakan hasil wawancara dengan anggota KWT sedangkan data sekunder diperoleh dari studi literatur dan dokumen instansi terkait. Tingkat kepuasan anggota terhadap peran kelompok dalam melaksanakan program pemanfaatan pekarangan dianalisis menggunakan pendekatan Customer Satisfaction Index (CSI) sedangkan faktor penentu ditentukan menggunakan analisis kuadran pada Importance Performance Analysis (IPA). Hasil penelitian menunjukkan bahwa anggota puas terhadap kinerja peran kelompok dalam pelaksanaan program KRPL yang ditunjukkan dengan nilai indeks CSI sebesar 0,80. Terdapat lima atribut yang menjadi penentu kepuasan anggota terhadap peran kelompok dalam pelaksanaan program KRPL yaitu merencanakan kebutuhan belajar, pengaturan pembagian tugas kelompok, merencanakan kegiatan kerjasama, merencanakan jenis bahan pangan yang akan dibudidayakan dan memfasilitasi ketersediaan benih/bibit.
\end{abstract}

Kata kunci: anggota, kelompok wanita tani, kepuasan, pekarangan, peran

\title{
PENDAHULUAN
}

Mencukupi kebutuhan pangan masyarakat merupakan salah satu tugas pemerintah. Berbagai upaya dilakukan untuk mencapai ketahanan pangan masyarakat salah satunya dengan program pemanfaatan pekarangan. Program ini hadir sebagai respon dari pertambahan luas pekarangan yang terus meningkat di tengah isu alih fungsi lahan pertanian. Badan Pusat Statistik mencatat bahwa luas lahan pekarangan pada tahun 2000 adalah seluas 5.132.000. Jumlah ini meningkat pada tahun 2010 menjadi seluas 10,3 juta ha. Salah satu penyebab peningkatan luas lahan pekarangan karena adanya peruntukan lahan pekarangan dalam setiap pembangunan perumahan dengan sistem horizontal (Arifin, 2013).

56 | Alfayanti; Lukman M Baga; Yusalina; Kepuasan Anggota Tehadap Peran... 
Salah satu program pemanfaatan pekarangan yang dilaksanakan pemerintah untuk menyediakan sumber pangan terjangkau bagi masyarakat adalah Kawasan Rumah Pangan Lestari (KRPL). Program ini telah dilaksanakan sejak tahun 2010 dan menjangkau seluruh wilayah baik perdesaan maupun perkotaan. Pelaksanaan program dilakukan dengan memberdayakan masyarakat dalam bentuk kelompok, salah satunya yaitu Kelompok Wanita Tani (KWT).

Tidak semua pelaksanaan program KRPL berlangsung secara berkelanjutan. Penelitian Fitrilia (2018) pada 15 lokasi yang melaksanakan program KRPL di Kota Malang dalam rentang tahun 2013 hingga tahun 2015, menunjukkan bahwa terdapat $72,72 \%$ KRPL tidak berlanjut (18,18\% mati dan $54,54 \%$ mati suri) sedangkan $27,28 \%$ KRPL berlanjut. KRPL yang tidak berlanjut dengan status mati menunjukkan kondisi kelompok pelaksana tidak melaksanakan dan tidak berkegiatan terkait KRPL. Sedangkan status mati suri menunjukkan kondisi dimana KRPL secara formal yaitu anggota KRPL masih ada, sisa dari pelaksanaan KRPL masih ada, dan kegiatan KRPL masih berlangsung walaupun tidak optimal.

Beberapa kendala dapat terjadi dalam pelaksanaan kegiatan pemanfaatan pekarangan terutama di wilayah perkotaan. Kepemilikan lahan pekarangan yang sempit (bahkan tanpa pekarangan), sulitnya akses terhadap sarana produksi seperti media tanam, benih/bibit, air dan pupuk organik, pilihan jenis komoditas yang terbatas, orientasi produksi yang belum berorientasi pasar, kurangnya pengalaman dalam bercocoktanam, dan keterbatasan modal menjadi beberapa contoh permasalahan (Saptana et al., 2011; Ashari et al., 2012; Wardoyo et al., 2013). Kelompok memiliki peran sebagai kelas belajar, wahana kerjasama dan unit produksi dapat menjadi sarana bagi peserta program dalam mengatasi kendala yang tidak bisa diselesaikan secara individu.

KWT Kentagor Mandiri merupakan salah satu KWT pelaksana KRPL di wilayah perkotaan yang melaksanakan program dari tahun 2018. Hingga memasuki tahap mandiri pada tahun 2020 beberapa kegiatan pendukung program masih berjalan aktif seperti pengelolaan demplot, kebun bibit serta pengembangan pekarangan anggota. Jumlah rumah pangan lestari (RPL) juga mengalami peningkatan dari 26 RPL pada tahu 2018 menjadi 34 RPL pada tahun 2020.

Keberhasilan pelaksanaan program KRPL di KWT Kentagor Mandiri tidak terlepas dari partisipasi aktif anggota dalam mendukung pelaksanaan program. Menurut Lee (2008) partisipasi merupakan faktor yang dapat mempengaruhi bertahannya suatu organisasi sehingga harus selalu dijaga bahkan ditingkatkan. Dalam pelaksanaan sebuah program, salah satu faktor yang dapat mempengaruhi partisipasi anggota adalah kepuasan terhadap peran kelompok dalam pelaksanaan program tersebut. Karena itu perlu diketahui tingkat dan atribut penentu kepuasan anggota terhadap peran kelompok. 
Penelitian ini bertujuan untuk menganalisis tingkat dan atribut penentu kepuasan anggota terhadap peran kelompok dalam pelaksanaan program KRPL di KWT Kentagor Mandiri. Hasil penelitian diharapkan dapat menjadi informasi bagi kelompok lain yang melaksanakan program serupa di wilayah perkotaan dan sebagai bahan pertimbangan bagi pihak terkait untuk kegiatan pembinaan maupun penetapan kebijakan.

\section{METODE PENELITIAN}

Penelitian dilaksanakan di KWT Kentagor Mandiri Kelurahan Kencana Kecamatan Tanah Sereal Kota Bogor pada bulan Desember 2019-Juni 2020. Lokasi dipilih secara sengaja (purposive sampling) karena KWT Kentagor Mandiri merupakan pelaksana program KRPL yang berada di wilayah perkotaan. KWT ini juga merupakan rujukan dalam pelaksanaan kegiatan pertanian perkotaan (urban farming) di Kota Bogor. Penentuan sampel dilakukan secara sensus sehingga semua anggota KWT menjadi sampel. Jumlah anggota KWT Kentagor Mandiri pada saat penelitian dilaksanakan berjumlah sebanyak 34 orang.

Data yang digunakan untuk mencapai tujuan penelitian adalah data primer dan data sekunder. Data primer dikumpulkan dengan melakukan pengamatan langsung di lokasi penelitian, wawancara dengan anggota kelompok menggunakan kuesioner serta diskusi dengan berbagai pihak seperti pengurus kelompok, penyuluh pendamping dan tokoh masyarakat. Kuesioner berupa daftar pertanyaan mengenai tingkat kepentingan dan tingkat kinerja atribut peran kelompok. Jawaban pertanyaan disusun dan diberi nilai menggunakan skala Likert yang memiliki lima pilihan jawaban dengan kriteria masing-masing (Tabel 1).

Tabel 1. Skor Penilaian Skala Likert Tingkat Kepentingan dan Tingkat Kinerja Atribut Peran KWT Tahun 2020

\begin{tabular}{llc}
\hline \multicolumn{1}{c}{ Tingkat kepentingan } & Tingkat kinerja & Skor/nilai \\
\hline Tidak penting & Tidak puas & 1 \\
Kurang penting & Kurang puas & 2 \\
Cukup penting & Cukup puas & 3 \\
Penting & Puas & 4 \\
Sangat Penting & Sangat puas & 5 \\
\hline
\end{tabular}

Sumber: Supranto (2011)

Data sekunder diperoleh melalui studi literatur dari berbagai dokumen. Dokumen dapat berupa laporan hasil penelitian, tulisan ilmiah, maupun laporan dari instansi terkait seperti Badan Pusat Statistik (BPS) dan Dinas Pertanian Ketahanan Pangan Kota Bogor.

Tingkat kepuasan anggota terhadap peran KWT dalam pelaksanaan program KRPL diukur menggunakan pendekatan Customer Satisfaction Index 
(CSI) dengan tahapan (Abdurahman \& Ferianda, (2014); Gama et al., (2016)):

1. Menentukan Mean Important Score (MIS) yang merupakan rata-rata nilai tingkat kepentingan setiap atribut penelitian.

2. Menentukan Mean Performance Score (MPS) yang merupakan rata-rata nilai tingkat kinerja setiap atribut penelitian.

3. Menentukan Weighting Factors (WF) yaitu persentase nilai MIS masing-masing atribut (MISi) terhadap MIS total untuk semua atribut yang diuji, dengan menggunakan persamaan:

$$
\mathrm{WFi}=\frac{\mathrm{MISi}}{\sum_{\mathrm{i}=1}^{\mathrm{n}} \mathrm{MISi}}
$$

4. Menentukan Weighted Score (WS) yang diperoleh dari hasil perkalian antara WF dengan MPS.

5. Menentukan nilai Weighted Average Total (WAT) yaitu total nilai WS seluruh atribut:

$\mathrm{WAT}=\mathrm{WS} 1+\mathrm{WS} 2+\ldots \ldots . .+\mathrm{WSn}$

$\mathrm{n}=$ jumlah seluruh atribut

6. Menentukan Customer Satisfaction Index (CSI) dengan cara membagi WAT dengan Highest Scale (HS). HS merupakan skala maksimum yang dipergunakan dalam penelitian

Kepuasan anggota terhadap peran kelompok disesuaikan dengan nilai indeks CSI dengan kriteria pada Tabel 2.

Tabel 2. Kriteria dan Nilai Customer Satisfaction Index (CSI)

\begin{tabular}{cl}
\hline Nilai CSI & \multicolumn{1}{c}{ Kriteria } \\
\hline $0,80<$ CSI $\leq 1,00$ & Sangat puas \\
$0,60<$ CSI $\leq 0,80$ & Puas \\
$0,40<$ CSI $\leq 0,60$ & Cukup puas \\
$0,20<$ CSI $\leq 0,40$ & Kurang puas \\
$0,00<$ CSI $\leq 0,20$ & Tidak puas \\
\hline
\end{tabular}

Sumber : Abdurrachman dan Ferianda (2014)

Penentuan atribut yang menjadi penentu kepuasan anggota terhadap peran kelompok dalam pelaksanaan program KRPL dilakukan dengan pendekatan analisis kuadran pada Importance Performance Analysis (IPA). Analisis kuadran membagi atribut ke dalam empat kuadran (Gambar 1). Atribut pada kuadran II merupakan penentu kepuasan anggota karena dianggap penting dan memiliki kinerja yang memuaskan. Atribut pada kuadran I dianggap sangat penting namun kinerjanya rendah sehingga harus menjadi prioritas untuk diperbaiki. Atribut pada kuadran III dianggap kurang penting pengaruhnya dengan kinerja yang kurang memuaskan. Sedangkan atribut pada 
kuadran IV merupakan atribut yang dianggap kurang penting namun kinerjanya sangat memuaskan.

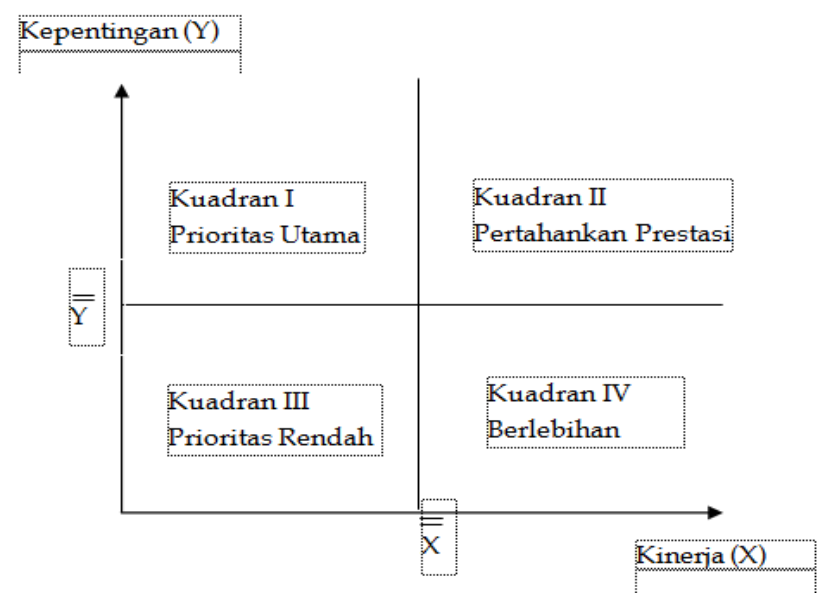

Gambar 1.

Diagram Kartesius Tingkat Kinerja dan Kepentingan

\section{HASIL DAN PEMBAHASAN}

\section{Gambaran Umum Lokasi Penelitian}

KWT Kentagor Mandiri berlokasi di Kelurahan Kencana Kecamatan Tanah Sereal Kota Bogor. Kelurahan seluas 227, 72 hektar ini terdiri dari 69 RT dan 14 RW. Badan Pusat Statistik (BPS) Kota Bogor mencatat bahwa jumlah penduduk Kelurahan Kencana pada tahun 2017 adalah sebanyak 28.231 jiwa. Wilayah perkotaan dengan jumlah populasi lebih dari 20 ribu jiwa tergolong sebagai wilayah dengan kepadatan rendah (Zasada et al., 2013).

Jumlah anggota KWT Kentagor Mandiri pada tahu 2020 tercatat sebanyak 34 orang dan rata-rata berusia 48,93 tahun. Jumlah anggota ini mengalami peningkatan sebesar $44 \%$ dari jumlah awal pada saat pembentukan kelompok di tahun 2016. Kegiatan kelompok dalam memanfaatkan pekarangan diduga menjadi daya tarik masyarakat untuk bergabung. Selain bisa mendapatkan aneka jenis sayuran dengan harga murah, kegiatan kelompok memberikan peluang terjadinya interaksi sosial pada anggota. Manfaat sosial merupakan manfaat yang paling banyak dirasakan oleh mayarakat perkotaan dalam kegiatan pemanfaatan pekarangan (Andrianyta et al., 2016).

Rata-rata pendapatan rumah tangga anggota setiap bulannya adalah $\mathrm{Rp}$ 4.762.300,-. Jumlah ini lebih tinggi dibandingkan dengan upah minimum regional (UMR) Kota Bogor tahun 2019 yang hanya sebesar Rp 3.842.785,- per

60 | Alfayanti; Lukman M Baga; Yusalina; Kepuasan Anggota Tehadap Peran... 
bulan. Hal ini mengindikasikan bahwa rumah tangga anggota kelompok memiliki kemampuan ekonomi untuk menuhan kebutuhan pangan keluarga.

Pendidikan formal yang sudah dijalani anggota KWT selama 12,33 tahun, hal ini menunjukkan bahwa pendidikan formal yang sudah dijalani ini sudah melampaui jenjang pendidikan dasar sembilan tahun. Rata-rata jumlah anggota keluarga sebanyak 4 orang. Jumlah ini sudah merujuk pada keluarga ideal menurut Badan Kependudukan dan Keluarga Berencana Nasional (BKKBN) karena terdiri dari aya, ibu, dan dua orang anak.

Rata-rata luas pekarangan responden adalah 4,12 $\mathrm{m}^{2}$. Responden dengan rumah tipe 36 dengan luas tanah $72 \mathrm{~m}^{2}$ tercatat sebanyak $82,35 \%$ sedangkan $17,65 \%$ lainnya menempati rumah tipe 45 dengan luas tanah $90 \mathrm{~m}^{2}$. Tidak semua responden menyisakan lahan untuk pekarangan. Sebanyak $44,12 \%$ responden tidak menyisakan lahan untuk pekarangan. Budidaya tanaman dilakukan menggunakan rak vertikultur yang diletakkan di depan rumah. Sebanyak $52,94 \%$ responden memiliki pekarangan seluas 3-9 $\mathrm{m}^{2}$ dan 2,94\% memiliki pekarangan seluas $18 \mathrm{~m}^{2}$. Responden dengan luas pekarangan ini selain menanam langsung di tanah juga menggunakan beberapa wadah tanam, seperti pot dan polibag.

\section{Tingkat Kepuasan Anggota Terhadap Peran Kelompok dalam Pelaksanaan Program KRPL}

Nilai indeks kepuasan anggota untuk semua atribut peran kelompok dalam pelaksanaan program KRPL menggunakan pendekatan CSI adalah sebesar 0,80 (Tabel 3). Nilai ini berada pada selang nilai CSI 0,60<CSI $\leq 0,80$ dengan kriteria puas (Tabel 2). Hal ini menginformasikan bahwa secara umum anggota KWT puas terhadap peran kelompok.

Tingkat kepuasan anggota terhadap peran kelompok sebagai kelas belajar dan wahana kerjasama berada pada kategori puas dengan nilai CSI 0,79. Kelompok pelaksana program KRPL mendapatkan pendampingan dan pelatihan yang diberikan oleh pendamping kelompok dan instansi terkait. Secara khusus, kegiatan pendampingan dan pelatihan KRPL memiliki tujuan untuk merubah sikap masyarakat serta meningkatkan pengetahuan, motivasi dan partisipasi masyarakat untuk terus berlanjut melaksanakan kegiatan pemanfaatan pekarangan (Kementan, 2018).

Peran KWT sebagai kelas belajar yang melaksanakan kegiatan seperti pertemuan rutin serta pembinaan dan pelatihan mampu meningkatkan pengetahuan, keterampilan dan sikap petani dalam kegiatan usahatani (Wastika et al., 2014; Lestari et al., 2018). Berbagai aktivitas belajar tersebut menambah pengetahuan anggota mengenai pemanfaatan dan merubah perilakunya (Fadhilah et al., 2017). Anggota yang sebelumnya hanya menggunakan tanah sebagai media tanam mulai menggunakan campuran tanah, kompos dan sekam. 
Limbah rumah tangga seperti air cucian beras yang biasanya dibuang juga telah dimanfaatkan sebagai pupuk organik.

Tabel 3. Indeks Kepuasan Anggota KWT Kentagor Mandiri Terhadap Peran KWT Dalam Pelaksanaan Program KRPL Tahun 2020

\begin{tabular}{|c|c|c|c|c|c|c|}
\hline Kode & Atribut & $\begin{array}{c}\text { Skor } \\
\text { kepentingan }\end{array}$ & $\begin{array}{c}\text { Skor } \\
\text { kinerja }\end{array}$ & WF & WS & CSI \\
\hline KB & Peran sebagai kelas belajar & & & & 3,96 & 0,79 \\
\hline KB1 & Merencanakan kebutuhan belajar & 4,64 & 4,67 & 0,15 & 0,73 & \\
\hline KB2 & $\begin{array}{l}\text { Melaksanakan perencanaan kebutuhan } \\
\text { belajar }\end{array}$ & 4,12 & 3,70 & 0,14 & 0,52 & \\
\hline KB3 & $\begin{array}{l}\text { Menjalin kerjasama dengan sumber } \\
\text { informasi }\end{array}$ & 3,91 & 3,97 & 0,13 & 0,53 & \\
\hline KB4 & $\begin{array}{l}\text { Melaksanakan pertemuan dengan } \\
\text { instansi terkait }\end{array}$ & 3,94 & 3,73 & 0,13 & 0,50 & \\
\hline KB5 & Kesesuain materi belajar & 4,30 & 3,76 & 0,14 & 0,55 & \\
\hline KB6 & Evaluasi kegiatan kerjasama & 4,30 & 3,88 & 0,14 & 0,57 & \\
\hline KB7 & $\begin{array}{l}\text { Meningkatkan keterampilan anggota } \\
\text { dan pengurus }\end{array}$ & 4,10 & 3,97 & 0,13 & 0,55 & \\
\hline WK & Peran sebagai wahana kerjasama & & & & 3,95 & 0,79 \\
\hline WK1 & Merencanakan kegiatan kerjasama & 4,60 & 4,30 & 0,11 & 0,49 & \\
\hline WK2 & $\begin{array}{l}\text { Merencanakan kegiatan pelestarian } \\
\text { lingkungan }\end{array}$ & 3,97 & 4,09 & 0,09 & 0,40 & \\
\hline WK3 & Mengembangkan aturan tertulis & 3,91 & 3,88 & 0,09 & 0,36 & \\
\hline WK4 & $\begin{array}{l}\text { Kerjasama dengan pihak penyedia } \\
\text { pupuk organik }\end{array}$ & 3,64 & 3,88 & 0,09 & 0,34 & \\
\hline WK5 & $\begin{array}{l}\text { Melaksanakan kegiatan pelestarian } \\
\text { lingkungan }\end{array}$ & 3,88 & 4,21 & 0,09 & 0,40 & \\
\hline WK6 & Mengatur pembagian tugas anggota & 4,73 & 4,39 & 0,11 & 0,51 & \\
\hline WK7 & Melaksanakan kesepakatan kelompok & 4,12 & 3,90 & 0,10 & 0,39 & \\
\hline WK8 & Mencatat kegiatan kerjasama & 4,00 & 3,90 & 0,09 & 0,38 & \\
\hline WK9 & $\begin{array}{l}\text { Evaluasi pelaksanaan kegiatan } \\
\text { kerjasama }\end{array}$ & 4,33 & 3,67 & 0,10 & 0,39 & \\
\hline WK10 & $\begin{array}{l}\text { Meningkatkan hubungan kerjasama } \\
\text { dengan mitra }\end{array}$ & 3,21 & 3,09 & 0,07 & 0,24 & \\
\hline$\overline{\mathrm{UP}}$ & Peran sebagai unit produksi & & & & 4,10 & 0,82 \\
\hline UP1 & $\begin{array}{l}\text { Merencanakan jenis bahan pangan yang } \\
\text { akan dibudidayakan }\end{array}$ & 4,33 & 4,24 & 0,10 & 0,44 & \\
\hline UP2 & $\begin{array}{l}\text { Merencanakan kebutuhan sarana } \\
\text { produksi }\end{array}$ & 4,00 & 4,27 & 0,09 & 0,41 & \\
\hline UP3 & Memfasilitasi penerapan teknologi & 3,91 & 4,20 & 0,09 & 0,40 & \\
\hline UP4 & $\begin{array}{l}\text { Melaksanakan kegiatan usahatani } \\
\text { bersama }\end{array}$ & 4,09 & 4,20 & 0,09 & 0,42 & \\
\hline UP5 & $\begin{array}{l}\text { Memfasilitasi ketersediaan pupuk } \\
\text { organik }\end{array}$ & 4,12 & 3,94 & 0,10 & 0,39 & \\
\hline UP6 & Memfasilitasi ketersediaan media tanam & 4,27 & 3,94 & 0,10 & 0,41 & \\
\hline UP7 & Memfasilitasi ketersediaan benih/bibit & 4,33 & 4,24 & 0,10 & 0,44 & \\
\hline UP8 & Pemupukan modal & 3,88 & 3,91 & 0,09 & 0,37 & \\
\hline UP9 & $\begin{array}{l}\text { Pengembangan fasilitas/sarana } \\
\text { pendukung kegiatan }\end{array}$ & 4,10 & 4,03 & 0,09 & 0,40 & \\
\hline \multirow[t]{2}{*}{ UP10 } & Evaluasi kegiatan budidaya & 3,94 & 3,94 & 0,09 & 0,37 & \\
\hline & Total & & & & 4,00 & 0,80 \\
\hline
\end{tabular}

Sumber: data primer diolah (2020)

Kegiatan belajar di KWT Kentagor Mandiri juga didukung oleh sarana belajar yang cukup memadai. KWT memanfaatkan lahan seluas $1.500 \mathrm{~m}^{2}$ milik 
salah seorang warga yang dipinjampakaikan kepada KWT sebagai lokasi demplot dan kebun bibit. Kegiatan pinjam pakai lahan ini telah diatur dalam perjanjian penggunaan lahan antara pemilik lahan dan ketua KWT. Kelompok memanfaatkan lahan tesebut sebagai demplot, kebun bibit dan lokasi pembangunan rumah bibit. Pada lokasi tersebut juga dibangun saung sebagai tempat pertemuan yang dilengkapi dengan fasilitas mushola dan toilet.

Anggota kelompok juga puas dengan peran KWT sebagai wahana kerjasama. Kerjasama dilakukan antar sesama anggota dalam satu kelompok dan dengan kelompok tani lain serta pihak terkait (Wastika, 2014). Kerjasama anggota dalam satu kelompok dilakukan dengan pembagian kerja melalui susunan struktur organisasi. Setiap bagian struktur memiliki tugas dan wewenang yang jelas. Selain itu, kerjasama juga diwujudkan dengan adanya pembagian tugas piket dalam pengelolaan kebun bibit dan demplot.

Kerjasama KWT dengan kelompok tani lain salah satunya dilaksanakan dalam penyediaan sarana produksi pupuk organik. Walaupun KWT telah berupaya membuat pupuk organik secara mandiri, namun produksinya tidak mencukupi untuk memenuhi kebutuhan kegiatan budidaya baik di lokasi demplot maupun pekarangan anggota. Oleh sebab itu KWT membeli pupuk organik yang dihasilkan oleh kelompok tani Mekar Mandiri yang berada di Kelurahan Bubulak Kabupaten Bogor.

Indeks CSI terhadap peran KWT sebagai unit produksi menunjukkan nilai paling tinggi dibanding dua peran lainnya. Hal ini disebabkan karena KWT dianggap telah mampu menyediakan dan memfasilitasi kebutuhan anggota berkaitan dengan kegiatan produksi. Sarana produksi seperti aneka bibit sayuran serta pupuk organik selalu tersedia di kebun bibit. Kedua sarana tersebut dapat dimanfaatkan oleh anggota secara gratis.

Bibit yang berasal dari kebun bibit selain ditanam di lokasi demplot juga dimanfaatkan untuk pengembangan pekarangan anggota. Contohnya pada tahun 2019 KWT membagikan sebanyak 651 polibag tanaman sayuran kepada anggota. Kepemilikan lahan pekarangan dan aktivitas anggota yang berbeda membuat jumlah polibag yang diberikan disesuaikan dengan luas lahan pekarangan atau berdasarkan jumlah polibag yang diminta. Bila terjadi kendala dalam kegiatan budidaya maka akan dicari upaya penyelesaiannya bersamasama. Selain berkonsultasi dengan pendamping kelompok, anggota juga saling bertukar pengalaman bila pernah mengalami kendala yang sama.

\section{Atribut Kepuasan Anggota Terhadap Peran KWT dalam Pelaksanaan Program KRPL}

Diagram kartesius analisis IPA menunjukkan bahwa terdapat tujuh atribut $(25,92 \%)$ berada pada kuadran I, lima atribut $(18,51 \%)$ terdapat pada kuadran II, sembilan atribut $(33,33 \%)$ pada kuadran III dan enam atribut $(22,22 \%)$ pada kuadran IV (Gambar 2). Lima atribut pada kuadran II yaitu: merencanakan 
kebutuhan belajar (KB1), merencanakan kegiatan kerjasama (WK1), pengaturan pembagian tugas kelompok (WK6), merencanakan bahan pangan yang akan dibudidayakan (UP1) dan memfasilitasi ketersediaan benih/bibit (UP7).

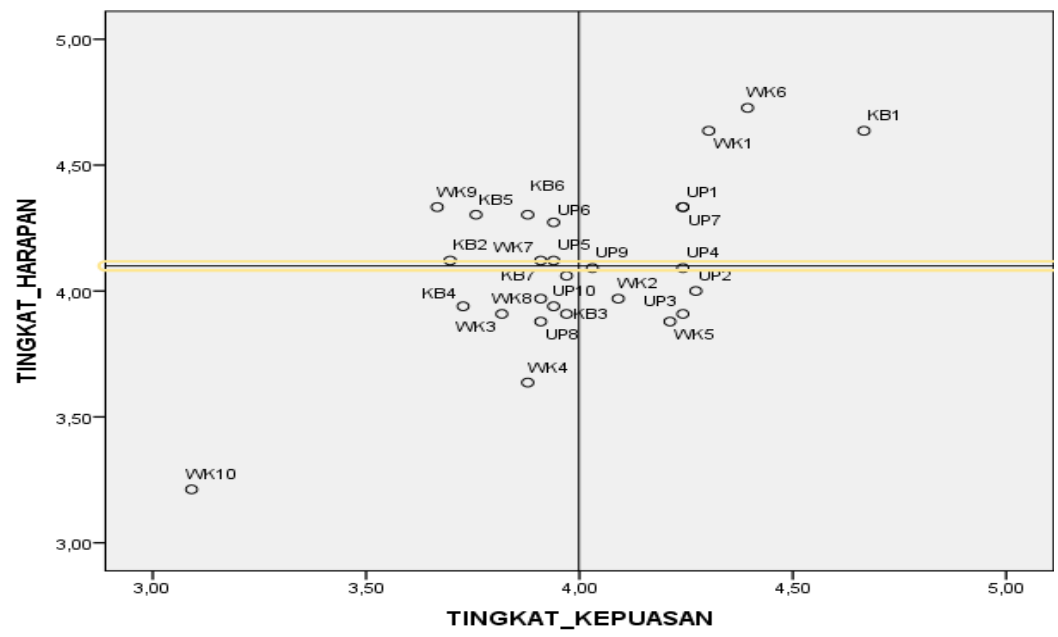

Gambar 2.

\section{Diagram Kartesius Kepuasan Anggota KWT Kentagor Mandiri Terhadap Peran Kelompok Dalam Pelaksanaan Program KRPL Tahun 2020}

Semua kegiatan perencanaan dalam setiap peran KWT baik sebagai kelas belajar, wahana kerjasama dan unit produksi berada pada kuadran ini. Hal ini menunjukkan bahwa anggota menilai kegiatan perencanaan aktivitas kelompok telah berjalan dengan baik. Perencanaan merupakan proses mempersiapkan kegiatan-kegiatan secara sistematik yang akan dilakukan untuk mencapai tujuan tertentu. Perencanaan kegiatan biasanya dibicarakan bersama dalam pertemuan rutin bulanan dan dihadiri oleh seluruh anggota. Anggota diberikan keleluasaan untuk menyampaikan usul seperti materi yang diinginkan atau jenis bahan pangan yang akan dibudidayakan. Artinya, pengambilan keputusan akan melibatkan dan diketahui oleh anggota. Pelibatan dalam pengambilan keputusan ini merupakan upaya untuk meningkatkan partisipasi anggota. Semakin banyak anggota terlibat dalam pengambilan keputusan maka partisipasinya semakin besar (Indardi, 2016)

KWT Kentagor Mandiri telah memiliki struktur kelompok yang terbagi menjadi ketua, sekretaris, bendahara, seksi (humas, sarana produksi, pemasaran, permodalan dan pengolahan pasca panen) dan anggota. Keberadaan struktur mengatur hubungan antar anggota kelompok berdasarkan peran dan norma (Rakhmat, 2007; Cartwright dan Zander, 1968). Interaksi ini memberikan gambaran kedudukan dan peran setiap anggota dalam upaya pencapaian tujuan. 
Selain pembagian tugas dalam bentuk struktur, pembagian tugas juga dilakukan dalam bentuk kelompok piket harian. Petugas piket berkewajiban melakukan perawatan tanaman yang berada di kebun bibit dan demplot sesuai dengan kondisi tanaman yang dibudidayakan. Kegiatan utama yang paling sering dilakukan adalah penyiraman dan pengendalian hama dan penyakit. Setiap anggota mendapatkan jadwal piket seminggu sekali.

Pemilihan jenis bahan pangan yang dibudidayakan dilakukan berdasarkan minat dan kebutuhan kelompok. Hasil kesepakatan inilah yang menjadi dasar penyediaan bibit di kebun bibit. Bibit selalu tersedia di kebun bibit dan dimanfaatkan pada kegiatan demplot maupun pengembangan pekarangan anggota. Anggota dapat memanfaatkan aneka bibit sesuai dengan kebutuhan. Ketersediaan bibit ini menjamin keberlanjutan kegiatan budidaya dan mempengaruhi keberhasilan pelaksanaan program (Sinarwati et al., 2015).

Kelompok juga selalu mencoba melakukan budidaya jenis bahan pangan baru di kebun bibit dan demplot. Hal ini dimaksudkan untuk menambah keanekaragaman varietas yang pernah dibudidayakan. Keragaman varietas yang dikembangkan di kebun bibit bermanfaat untuk meningkatkan kesadaran masyarakat akan pelestarian varietas lokal, pengetahuan varietas hibrida, peningkatan ilmu cara budidaya dan koleksi tanaman serta upaya optimalisasi pemanfaatan pekarangan (Aristya, 2012).

Selain mempertahankan kinerja atribut pada kuadran II, KWT juga harus memperhatikan kinerja atribut pada kuadran I. Atribut pada kuadran ini merupakan atribut yang dinilai penting oleh anggota namun kinerjanya belum memuaskan. Atribut yang terdapat di kuadran I antara lain pelaksanaan perencanaan kebutuhan belajar (KB2), kesesuaian materi belajar (KB5), evaluasi kegiatan belajar (KB6), pelaksanaan kesepakatan kelompok (WK7), evaluasi pelaksanaan kegiatan kerjasama (WK9), fasilitasi ketersediaan pupuk organik (UP5), dan fasilitasi ketersediaan media tanam (UP6).

Dalam melaksanakan program KRPL, KWT didampingi oleh petugas pendamping yang bertugas untuk membimbing kelompok melalui pendampingan dan pelatihan. Pelaksanaan kegiatan di lapangan seperti materi pembinaan diberikan berdasarkan penjabaran dari petunjuk teknis yang telah disusun. Adanya regulasi berupa petunjuk teknis ini cukup membatasi variasi materi yang sesuai dengan keinginan peserta program. Pendamping kelompok diharapkan mampu mengatur jenis materi yang disampaikan dalam kegiatan belajar. Hal ini dilakukan agar materi yang sesuai dengan petunjuk teknis dapat tersampaikan namun informasi mengenai pemanfaatan pekarangan yang dibutuhkan anggota juga dapat terpenuhi.

Anggota menilai kinerja pelaksanaan kesepakatan kelompok masih belum memuaskan. Salah satu kesepakatan yang pelaksanaannya tidak sesuai harapan anggota adalah pemberian sanksi bagi anggota yang tidak aktif dalam kegiatan KWT dan tugas piket. Pengurus belum bersedia menjalankan kesepakatan ini 
karena keikutsertan sebagai anggota KWT masih bersifat sukarela. Karena itu perlu adanya motivasi bagi anggota agar dapat terus aktif dalam kegiatan kelompok. Motivasi dapat diberikan oleh sesama anggota maupun pendamping kelompok. Pendamping dapat memberikan semangat sosial seperti menginspirasi, menstimulasi, menggerakkan orang yang didampingi turut terlibat dalam aktifitas bersama (Ife dan Tesoriero, 2006)

Sebagian anggota merawat tanaman tanpa menambah pupuk atau media tanam tambahan hingga tanaman dapat di panen. Walaupun media tanam dalam polibag biasanya akan menyusut setelah dilakukan penyiraman. Tetapi ada juga anggota yang berinisiatif untuk menambah media tanam bahkan jumlah tanaman yang dibudidayakan. Hal ini tentu saja menyebabkan anggota tersebut membutuhkan media tanam dan pupuk organik yang lebih banyak.

Pupuk organik selalu tersedia di lokasi demplot. Media tanam siap pakai tersedia bila kelompok akan melaksanakan kegiatan pembibitan maupun penanaman. Anggota diperbolehkan mengambil kedua sarana ini sesuai dengan yang dibutuhkan tanpa harus membayar. Namun anggota yang membudidayakan tanaman yang lebih banyak merasa sungkan bila harus mengambil lebih banyak. Kelompok perlu menegaskan kembali tentang hak dan kewajiban anggota dalam pelaksanaan kegiatan kelompok. Hak dan kewajiban anggota yang kurang jelas dapat berimplikasi pada keseriusan anggota dalam menjalankan program kelompok (Hanggana, 2017). Keterbukaan antar individu dapat menjadi pengikat untuk mendorong tumbuh berkembangnya organisasi dalam mencapai tujuan (Wahid, 2008).

\section{SIMPULAN DAN SARAN}

\section{Simpulan}

1. Tingkat kepuasan anggota memiliki nilai indeks sebesar 0,80 yang berarti anggota puas terhadap peran kelompok dalam pelaksanaan program KRPL.

2. Terdapat lima atribut yang menjadi penentu kepuasan anggota terhadap peran kelompok dalam pelaksanaan program KRPL yaitu merencanakan kebutuhan belajar, pengaturan pembagian tugas kelompok, merencanakan kegiatan kerjasama, merencanakan jenis bahan pangan yang akan dibudidayakan dan memfasilitasi ketersediaan benih/bibit.

\section{Saran}

1. KWT diharapkan dapat mempertahankan kinerja atribut pada kuadran II untuk keberlanjutan program. Hal ini juga dibarengi dengan meningkatkan kinerja atribut pada kuadran I, mengurangi kinerja atribut pada kuadran IV dan mempertimbangkan perbaikan atribut yang masuk dalam kuadran III agar tidak bergeser ke kuadran I.

66 | Alfayanti; Lukman M Baga; Yusalina; Kepuasan Anggota Tehadap Peran... 
2. Mengoptimalkan peran pendamping kelompok dengan membangun kerja kelompok dan keswadayaan peserta program .

\section{DAFTAR PUSTAKA}

Abdurrachman dan Ferianda. 2014. Analisis Tingkat Kepuasan Petani Terhadap Benih Padi Varietas PB42 Di Kecamatan Manyak Payed Kabupaten Aceh Tamiang. Jurnal Penelitian Agrisamudra. 2(1): 1-10.

Andrianyta Harmi, Amalia Ulpah, dan Hari Hermawan. 2016. Dampak Pemanfaatan Pekarangan dalam Perspektif Sosial dan Ekonomi di Kalimantan Timur. Prosiding Seminar Nasional Inovasi Teknologi Pertanian. Balai Pengkajian Teknologi Pertanian Kalimantan Selatan

Arifin Hadi Susilo. 2013. Pekarangan Kampung Untuk Konservasi AgroBiodiversitas Dalam Mendukung Penganekaragaman Dan Ketahanan Pangan Di Indonesia. Makalah orasi ilmiah guru besar. IPBAristya Vina Eka. 2012. Keragaman Varietas Melalui Pengelolaan Kebun Bibit Desa Sebagai Upaya Optimalisasi Pemanfaatan Lahan Pekarangan. Prosiding Seminar Nasional Optimalisasi Lahan Pekarangan untuk Peningkatan Perekonomian Masyarakat dan Pengembangan Agribisnis. UNDIP Press.

Ashari, Saptana, dan Tri Bastuti Purwantini. 2012. Potensi Dan Prospek

Pemanfaatan Lahan Pekarangan Untuk Mendukung Ketahanan Pangan. Forum Penelitian Agro Ekonomi. 30 (1): 13-30.

Cartwright Dorwin dan Zander Alvin. 1968. Group Dynamic: Research and Theory.

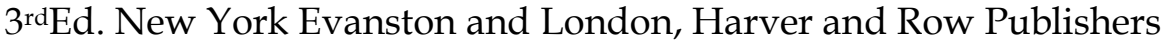

Fadhilah ML, Eddy BT, dan Gayatri S. 2017. Pengaruh Tingkat Pengetahuan,

Sikap dan Keterampilan Penerapan Sistem Agribisnis Terhadap Produksi Pada Petani Padi di Kecamatan Cimanggu Kabupaten Cilacap.Jurnal Agrisocionomics. 2(1). 39-49.

Fitrilia Ranikirana Masya. 2018. Keberlanjutan Kawasan Rumah Pangan Lestrai (KRPL) di Kota Malang (Studi Kasus pada 11 Kelurahan). Thesis Sarjana Jurusan Agribisnis Fakultas Pertanian Universitas Brawijaya. Malang. Tidak Dipublikasikan.

Gama I Gusti Made, Rina Oktaviani, dan Amzul Rifin. 2016. Analisis Kepuasan Petani Terhadap Penggunaan Pupuk Organik Pada Tanaman Padi. Jurnal Agro Ekonomi. 34 (2): 105-122.

Hanggana Sri. 2017. Analisis Kelemahan Regulasi Poktan Gapoktan UPJA dan LKM_A dalam Peningkatan Pendapatan Petani. Jurnal Analisis Kebijakan Pertanian. 15 (2):137-149

Ife Jim dan Fran Tesoriero. 2006. Community Development: Alternatif Pengembangan Masyarakat di Era Globalisasi. Yogyakarta, Penerbit Pustaka Pelajar. 
Indardi. 2016. Pengembangan Model Komunikasi Dalam Pemberdayaan Masyarakat Tani. Jurnal Agraris. 2 (1): 75-86

Kementerian Pertanian. 2018. Petunjuk Teknis Optimalisasi Pemanfaatan Lahan Pekarangan Melalui Kawasan Rumah Pangan Lestari (KRPL) Tahun 2018. Jakarta, Kementerian Pertanian Republik Indonesia

Lee Andrea. 2008. Staff Management: Kiat Menciptakan Lingkungan Kerja dan Hidup Pribadi Karyawan yang Seimbang. (terj). Jakarta, Penerbit Prestasi Pustakaraya

Lestari Wahyu Puji, Diah Mardiningsih, dan Siwi Gayatri. 2018. Peran Kelompok Tani Terhadap Tingkat Pengetahuan Petani Jambu Biji Getasmerah Di Kelompok Tani Makmur Kecamatan Pagerruyung Kabupaten Kendal. Jurnal Agrisaintifika. 2 (1): 84-93

Rakhmat Jalaluddin. 2007. Psikologi Komunikasi. Bandung, Penerbit Remaja Rosdakarya

Saptana, I Wayan Rusastra, Sri H Susilowati, Jefferson Situmorang, Ashari, Tri

Bastuti Purwantini, Yana Supriyatna, Tjetjep Nurasa, Sri Suharyono, dan Ahmad M Arrozi. 2011. Dampak pengembangan Model Kawasan Rumah Pangan Lestari (MKRPL) terhadap kesejahteraan rumah tangga dan ekonomi di perdesaan. Laporan Penelitian. Bogor. Pusat Sosial Ekonomi dan Kebijakan Pertanian

Sirnawati Enti, Astrina Yulianti, dan Amalia Ulpah. 2015. Faktor-Faktor Yang Mempengaruhi Keberhasilan Kawasan Rumah Pangan Lestari di Pulau Sumatera. Junal Pengkajian dan Pembangunan Teknologi Pertanian. 18 (1): $11-27$

Supranto. 2011. Pengukuran Tingkat Kepuasan Pelanggan Untuk Menaikkan Pangsa Pasar. Cet. Ke-4. Jakarta, Penerbit PT Rineka Cipta

Wahid Abdul. 2008. Dinamika Kelompok Tani Pada Kegiatan Rehabilitasi Hutan dan Lahan di DAS Bila Walanae Desa Lasiwala Kabupaten Sidrap. Jurnal Hutan dan Masyarakat. 3 (2): 111-234

Wardoyo Akhmad Susilo, Sigit Waluyo, Karyanto. 2013. Pemanfaatan Pekarangan Dan Teras Rumah Di Kawasan Tengah Kota Sebagai Suatu Kawasan Rumah Pangan Lestari (KRPL). Laporan Penelitian. Universtas Terbuka UPBJJ Malang

Wastika Chindra Yeni, Sunarru Samsu Hariadi, dan Subejo. 2014. Peran Kelompok Tani Dalam Penerapan Sri (System Of Rice Intensification) Di Kecamatan Kalikajan Kabupaten Wonosobo. Jurnal Agro Ekonomi. 24(1) : $84-93$.

Zasada Ingo, Wolfgang Loibl, Mario Kostl, dan Annette Piorr. 2013. Agriculture Under Human Influence: A Spatialanalysis of Farming System And Land Uses In European Rural-Urban-Region. European Countryside. 5: 71-88

68 | Alfayanti; Lukman M Baga; Yusalina; Kepuasan Anggota Tehadap Peran... 